\title{
Ventos do Apocalipse: as representações da vida e da morte em imagens de violência e guerra
}

\author{
Katya Queiroz Alencar*
}

\begin{abstract}
RESUMO
O objetivo deste artigo é promover discussões e reflexões sobre como o romance Ventos do Apocalipse, da escritora Paulina Chiziane, se constrói como um testemunho dos traumas da guerra civil moçambicana, articulando as categorias vida e morte a partir de imagens de violência e guerra. Para tanto, usaremos discussões sobre a legitimação da violência na literatura, trauma, testemunho, história, narrador e realismo nas perspectivas de Jaime Ginzburg, que analisa o pensamento de Hegel e Adorno, Márcio Seligmann-Silva, Cathy Caruth, Walter Benjamin e Tânia Pellegrini. A nossa hipótese é que Ventos do Apocalipse se estrutura em um eixo dialógico e deslizante de duas categorias, vida e morte, em torno do qual são tecidas imagens de violência e guerra a partir de ações que constroem a diegese do romance e reforçam, concomitantemente, um comprometimento ético da escritora Chiziane com o testemunho do trauma da guerra civil vivido pelo povo moçambicano.

Palavras-chave: Literatura africana. Guerra. Violência. Trauma. Testemunho. Vida. Morte.
\end{abstract}

Vinde todos e ouvi

Vinde todos com as vossas mulheres

E ouvi a chamada.

Não quereis a nova música de timbila

Que me vem do coração?

(CHIZIANE, 1999, p. 13)

\section{A literatura em Moçambique}

A formação das literaturas africanas de Língua Portuguesa pode ser associada com a própria história da política colonial europeia e com contextos de guerras e de violências, servindo-se, muitas vezes, como processo de resistência africana ao

* Universidade Estadual de Montes Claros - UNIMONTES 
regime autoritário praticado pelos países colonizadores. No final do século XIX, a partir da Conferência de Berlim (1884-1885) ${ }^{1}$ e do Ultimatum inglês (1890)2, Portugal, assim como outros países colonizadores europeus, adotou uma política colonial brutal e opressora em suas colônias. Nesse contexto surgiram medidas de assimilação, como as Guerras de Pacificação, que pregavam que o homem negro era selvagem e inferior ao branco em termos raciais, devendo aquele ser tutelado e civilizado pelo colonizador. Os mestiços, nessa época, sofriam discriminações, uma vez que se acreditava na ideologia de que eles carregavam os traços ruins das raças envolvidas. A mulher negra, inclusive, segundo o poeta Arlindo Barbeitos, também historiador angolano, ao investigar a desvalorização dessa mulher na obra de Oliveira Martins, aponta como Martins era conivente com essa ideologia discriminatória colonial: “[...] Ela [mulher negra] é um ser imundo, fraco e doente organicamente pelas regras periódicas e pela prenhez... farrapo depois do uso, mísera, abjecta depois de reinar sobre a paixão sensual humana." (MARTINS apud BARBEITOS, 2000, p. 603).

Outro fator de agravamento da situação de opressão nas colônias portuguesas foi a instalação, no período de 1928 a 1974, em Portugal, da ditadura fascista sob o comando de Antonio de Oliveira Salazar, que, para garantir os serviços no estrangeiro, criou a Polícia Internacional e de Defesa do Estado - PIDE. A PIDE desempenhou, nas colônias portuguesas, funções administrativas, de prevenção criminal e ainda de repressão, perseguindo, inclusive, escritores nacionalistas africanos. Muitos métodos escusos, como a prisão sem justificativa e a tortura, foram usados pela PIDE tanto em Portugal como nas colônias. Há registros que apontam que vários escritores africanos se rebelaram contra o regime opressivo de Portugal nas colônias, e alguns foram presos ao longo das décadas de 1950 a 1970 por suas manifestações literárias de caráter crítico-nacionalista, engajadas e combativas. Sendo assim, a formação da literatura africana de língua portuguesa esteve, desde o início, perpassada por contextos de guerra e violência: primeiramente, por manifestações que defendiam a luta pela independência e, posteriormente, pelo enfrentamento de uma maneira ou de outra por parte de países como Angola, Moçambique, Cabo Verde, Trindade e Príncipe e Guiné Bissau de

1 A Conferência de Berlim teve por objetivo estabelecer regras para reorganizar a ocupação de África pelas potências coloniais, e nessa nova política não foram respeitadas nem a história, nem a etnia e muito menos a cultura e tradições dos povos do continente africano.

2 O Ultimatum inglês consistiu em um telegrama enviado ao governo português pelas autoridades inglesas em 11 de janeiro de 1890, que exigia a retirada imediata das forças militares portuguesas mobilizadas nos territórios entre Angola e Moçambique. Caso a exigência não fosse cumprida por Portugal, a Inglaterra avançaria sobre o país com uma intervenção militar. 
realidades ligadas à guerra civil pós-independência.

Em Moçambique, o cenário não foi diferente, e a literatura também surgiu em conjunturas de guerras. Segundo Ana Mafalda Leite (2008), as manifestações de uma literatura nacional moçambicana, desde os primórdios de seu surgimento, estiveram comprometidas com o combate à discriminação e o racismo que caracterizavam o novo colonialismo português e a guerra civil instaurada no país depois da independência. Para Leite, essas manifestações eram fomentadas por jornalistas, ligados à imprensa moçambicana em jornais, tais como $\mathbf{O}$ Africano (1908), O Brado Africano (1918) e revistas como Itinerários (1950), Msaho (1952), dentre outras. Ainda segundo Leite, esses primeiros jornalistas escritores escreviam com a "finalidade [de] defender os interesses do grupo e da população negra contra as novas tendências discriminatórias". (LEITE, 2008, p. 65).

É válido lembrar que a guerra de independência em Moçambique teve início em 1964 e terminou em 1974; a guerra civil começou logo em seguida, em 1976, e durou até 1992. O governo instaurado em Moçambique foi o de orientação comunista, e a Frente para a Libertação de Moçambique - FRELIMO - assumiu o poder por unanimidade. Porém, logo após a FRELIMO subir ao poder, iniciaramse os embates políticos com a Resistência Nacional Moçambicana - RENAMO -, responsável pela formação de guerrilhas que visavam a derrubar o governo moçambicano recém-instalado.

Nesse cenário recortado por guerras, em que a vida e a morte estavam na pauta do dia, a literatura moçambicana foi se consolidando. Segundo Maria Nazareth Soares Fonseca e Terezinha Taborda Moreira (2007), a literatura moçambicana pode ser dividida historicamente em três momentos: o primeiro, caracterizado pela resistência ao regime colonizador português e pela aspiração à construção de uma história nacional a partir da luta pela independência do país; o segundo, a partir de 1975, configurado principalmente pela poesia de combate, praticada, sobretudo, por militantes ligados à FRELIMO; e o terceiro momento, a partir de 1992, marcado por uma literatura plural, que constitui-se pelo mosaico de temas agregados por experimentações estéticas, tendo os escritores tons mais intimistas nos relatos das experiências pós-coloniais.

Paulina Chiziane pertence ao terceiro momento da literatura moçambicana. Ela faz parte do grupo de escritores desse país que retomam relatos da guerra, experimentando novas estéticas literárias. O seu romance Ventos do Apocalipse foi escrito em 1999 e aborda a brutalidade da guerra civil e da situação de extrema miséria e violência dos sobreviventes nesse conflito. O objetivo deste estudo, portanto, é explorar como o romance Ventos do Apocalipse se constrói como 
testemunho dos traumas da guerra civil moçambicana. Para isso fizemos um recorte das categorias vida e morte em Ventos do Apocalipse a partir de imagens de violência e guerra que serão analisadas. A nossa hipótese é que Ventos do Apocalipse se estrutura por um eixo dialógico e deslizante dessas duas categorias, vida e morte, e que, em torno desse eixo, são tecidas imagens de violência e de guerra a partir de ações que constroem a diegese e também confirmam um comprometimento ético da escritora Chiziane com o testemunho do trauma da guerra civil moçambicana.

\section{Karingana wa karingana, "era uma vez" três breves histórias de violência e guerra}

A narrativa Ventos do Apocalipse inicia-se com uma invocação para a "nova música". Há um prólogo em que o narrador, em primeira pessoa, deseja contar histórias antigas de todos os tempos, "lamentos que saem da alma". (CHIZIANE, 1999, p. 15). Histórias de circularidade da vida e da morte: "Quero contar-vos histórias antigas, do presente e do futuro porque tenho todas as idades e ainda sou mais novo que todos os filhos e netos que hão-de nascer". (CHIZIANE, 1999, p. 15). O narrador, assim como um oráculo, prenuncia um chamado que falará da guerra, da fome e do terror, mas também da natureza, da vida e da tradição. Ele apresenta para o leitor a terra de Mananga, aldeia africana no passado, em que a representação da vida era o verde dos campos exagerados. Como o próprio narrador afirma, "era terra do paraíso". (CHIZIANE, 1999, p. 15). A tradição, ainda conforme esse narrador, mediava o diálogo com os deuses da chuva. Essa visão paradisíaca mitifica inicialmente a vida na aldeia como estado de perfeição e marca, também, uma perspectiva da memória cultural de um povo.

Karingana wa karingana, "era uma vez" três breves histórias que antecipam, no prólogo, em uma perspectiva de prolepse, a confabulação entre a morte e a vida. Essa confabulação é evidenciada pela violência e pela guerra que a tensiona e que também marcará a continuidade do trágico diálogo morte e vida ao estruturar a estória principal da obra em análise.

No prólogo, a primeira das três narrativas curtas que o compõem se intitula "Marido cruel", e nela o narrador deixa claro para o leitor que foi a partir das "infâmias das novas gerações [que] os deuses começaram a vingar-se [...]". (CHIZIANE, 1999, p. 16). Ele deixa disseminada a ideia de que essa vingança, ao que tudo aponta, tem como uma das faces a imagem da fome e do sol, inimigos 
eleitos por um povo que aprendeu, por força da necessidade, a matar, a enganar uns aos outros na luta para sobreviver. Esse pequeno relato já preanuncia que a guerra pela sobrevivência e pelo poder tribal derramará cruelmente sangue entre irmãos e soprará a dor e o terror nas narrativas seguintes do romance.

Na segunda narrativa introdutória, cujo título é "Mata, que amanhã faremos outro", evidencia-se um discurso da tradição de Mananga, em que, para a manutenção da vida, muitas vezes era necessário sacrificar outras vidas. A morte e a vida, nesse viés de pensamento, parecem se irmanar, e a "solidariedade é a lei: ou morre um por todos ou todos por um". (CHIZIANE, 1999, p. 19). Isso evidencia que, na tradição do povo de Mananga, em tempos de guerra, matar uma criança que chora é norma de segurança, pois é mais válido perder um filho do que perder a guerra. Sendo assim, o choro de uma criança assustada é silenciado pela mão da morte, que a asfixia, pois, segundo os seus próprios pais que a assassinam, "amanhã faremos outro". (CHIZIANE, 1999, p. 19). E sobre esse assunto, o narrador deixa uma pergunta para o leitor: "a quem comovem as lágrimas no tempo de guerra?" (CHIZIANE, 1999, p. 19).

Já a terceira breve história introdutória de Ventos do Apocalipse, ainda no prólogo, salienta a ambição de uma mulher: a de Massupai, a negra sereia das terras chopes, que por ambição e poder mata os seus filhos para viver ao lado do general. Seu desejo vem enlaçado com o sangue dos próprios filhos e, no final da breve narrativa, Massupai enlouquece e, morta-viva, como um zumbi, se torna lenda: "começando a revolver as sepulturas com as mãos, para ressuscitar os seus filhos que perdera". (CHIZIANE, 1999, p. 22).

Nesse eixo dialógico da vida com a morte, Ventos do Apocalipse traz um provérbio e um fragmento de uma canção popular que evidencia a aproximação desses temas em um circuito eterno de repetições: "A terra gira e gira, a vida é uma roda, chegou a hora, a história repete-se”. (CHIZIANE, 1999, p. 22). Vale lembrar, entretanto, que a vida e a morte não são categorias que se opõem na narrativa, mas sobretudo se complementam e permitem a ideia de continuidade. Elas são tratadas por Chiziane como uma só categoria, que obrigatoriamente se relacionam dialeticamente, sendo a guerra parte do material que estrutura o eixo no qual giram a morte e a vida: "A diversão do homem consiste em destruir e construir desde o princípio do mundo. As guerras existirão sempre”. (CHIZIANE, 1999, p. 136).

O prólogo, portanto, tem uma perspectiva estética performática, uma vez que antecipa em resumo a ambígua relação de circularidade da vida e da morte que será retomada e expandida nas partes I e II do romance. A própria epígrafe que introduz a parte I do romance confirma isso. Ela é um provérbio que diz sobre a 
vida das novas gerações verão a morte e a destruição: "Nasceste tarde! Verás o que eu não vi”. (CHIZIANE, 1999, p. 23). Fragmentos de uma canção popular também tratam a sincronicidade da vida e da morte na segunda parte do romance, quando falam sobre o que se passa entre o fim e o início da existência humana - histórias que se repetem: "cada dia tem a sua história". (CHIZIANE, 1999, p. 143). Isso possibilita a inferência de que há um fluxo poético de repetições figurativas desses temas em toda a estrutura do projeto escritural de Chiziane em análise.

Diante de constatações como essas, foi possível fazer alguns recortes de representações do tema da morte e da vida que se nutrem, no romance, de variados campos semânticos figurativos. Essas representações dialogam entre si, na maioria das vezes, circuladas por imagens de guerra e violência. Selecionamos algumas dessas representações para serem discutidas.

\section{Karingana wa Karingana, "era uma vez" a circular ambiguidade da morte e da vida}

Na primeira parte do romance há palavras, imagens, cenas que podem ser associadas à linha temática da vida e também da morte. Muitas dessas cenas que caracterizam a morte se associam ao quase extermínio do povo de Mananga (ação clímax da primeira parte). A categoria da morte se faz representar metaforicamente e metonimicamente em diversas passagens do romance.

Uma dessas passagens diz respeito ao diálogo de Sianga com os defuntos: "Escutai defuntos, amparai defuntos, abri as vossas portas para o filho que sofre [...]". (CHIZIANE, 1999, p. 26). Em outra, a fome e a seca sinalizam a morte na terra de Mananga: "Minosse Wê, foi a fome que te ensurdeceu?". (CHIZIANE, 1999, p. 27).

Muitas são as figuras da morte construídas por Chiziane no romance. Elas aparecem no silêncio que antecipa a morte, na desgraça, na ausência, na dor e nas interrupções ou não da palavra, como o próprio narrador comenta: "Quando os mudos falam, é chegada a hora fatal, é o mau agoiro”. (CHIZIANE, 1999, p. 30). A morte também é perceptível no tom da desonestidade, da traição, da vingança e da conspiração recorrentes no enredo da história e que também marcam a guerra pela sobrevivência em Mananga, lugar inóspito e pobre. Ela, a morte, também se transfigura nas tradições que sofrem alterações ao longo do tempo: "[a] revolução transformou tudo". (CHIZIANE, 1999, p. 61). Nesse cenário de desolação, tradições africanas centenárias morrem e isto é registrado por Chiziane como um 
problema para a cultura nativa:

Mataram os velhos, mataram os novos. O povo não tem biblioteca e nem escreve. A sua história, os seus segredos residem na massa cinzenta dos antigos, cada cabeça é um capítulo, um livro uma enciclopédia, uma biblioteca. As cabeças foram decepadas e em breve será o enterro. (CHIZIANE, 1999, p. 132).

É possível ainda perceber a negatividade figurativa da morte no ressentimento de Sianga ao perder o posto de régulo de Mananga, no luto, no ciclo da natureza que foi quebrado: "os tempos são maus, maus mesmos [...]. A natureza quebrou o seu ciclo e os corpos andam em andrajos". (CHIZIANE, 1999, p. 57).

A natureza, no romance, também personifica a morte no cenário que habita o sol, que, nessa primeira parte da narrativa, é motivo de castigo, fome e crueldade para a aldeia Mananga, que vive a decadência animalizada de seu povo: "Estou no mesmo lugar a observar a decadência do mundo, o desnudar da terra (...) comparo a luta dos lagartos à luta dos galos e dos homens”. (CHIZIANE, 1999, p. 65). Percebe-se que ora a natureza se apresenta indiferente ao sofrimento do homem, ora ela anuncia, no romance, o rio de sangue que correrá por ele todo. Há uma visão animista, na qual tudo tem vida. Nesse contexto, é possível identificar o vento como uma força ativa no romance.

O tema da morte também dialoga, nessa primeira parte do romance, com o texto bíblico cristão disseminado na narrativa, assim recortado: "Há cavaleiros no céu, o som das trombetas escuta-se." (CHIZIANE, 1999, p. 47). Passagens do livro do Apocalipse bíblico cristão são parafraseadas pelo narrador, que cita os quatro cavaleiros do Apocalipse como precursores da morte. Nota-se o canto da morte, e esteticamente esse canto tem um refrão que se repete em alguns desses trechos: "é tempo de cavarmos as nossas sepulturas, yo!" (CHIZIANE, 1999, p. 47-48-55).

Em outro momento, a morte na obra de Chiziane é a da traição e da figura da serpente: Sianga, "homem inútil” (CHIZIANE, 1999, p. 64), assim diz o narrador. $\mathrm{O}$ comportamento de Sianga, ex-régulo da terra, é associado à figura da serpente do mal bíblico, que usa a sua ambição, juntamente com os seus comparsas, para iniciar uma conspiração a fim de retomar o poder da tribo. A linguagem figurada se institui como uma profecia bíblica: "o segundo cavaleiro é escravo na hora e comandante do batalhão genocida. Paira no céu de Mananga, galopando serpentinamente nas ondas do vento." (CHIZIANE, 1999, p. 48). Para 
Sianga e todos os seus antepassados, a conquista do poder nas tribos somente se justificava através da guerra e da violência. A categoria do homem é animalizada: "homens e bichos são feras fabricadas pelo mesmo diabo" (CHIZIANE, 1999, p. 65), e, portanto, percebe-se que, para aquele povo, o uso da violência para a sobrevivência da espécie era algo que já fazia parte de sua vida.

Em perspectiva teórica sobre esse assunto, vale citar Jaime Ginzburg (2012), que, se valendo das ideias de Hegel, aborda a legitimação da violência pela literatura e pela História. Para Hegel, o herói da epopeia grega carrega em si propriedades humanas e individuais, nacionais e coletivas, e, portanto, há nele uma disposição para o comportamento cruel e para a ação com violência que justificaria a finalidade de suas ações e a síntese harmônica das mesmas na conquista e unificação de um povo. O herói hegeliano é determinado pelo destino, uma força exterior a ele. Assim também podemos pensar na possibilidade de as ações cruéis de Sianga terem sido motivadas por agentes externos, como, por exemplo, a fome. $\mathrm{Na}$ perspectiva do pensamento de Hegel, a guerra e as mortes sucedidas pelas ações de Sianga poderiam até ser justificadas, porque havia um sonho de Sianga de restituição de uma tradição que ele mesmo representava: a dos régulos. E mesmo cruéis, traiçoeiras, essas ações individuais de Sianga de retomada de poder tinham, a priori, uma motivação talvez até inconsciente de unidade tribal. Todavia, essa perspectiva é logo desconstruída por Chiziane, pois Sianga não tem a face do herói hegeliano, uma vez que nada uniu a partir de seus atos cruéis e traiçoeiros. Sianga não realizou nenhuma síntese positiva da violência que promoveu em sua aldeia. Pelo contrário, Mananga foi dizimada, os corpos humanos queimados vivos, e os filhos de Sianga assassinaram-se mutuamente. Tudo foi destruído, inclusive o sonho de poder do régulo, e Sianga e seus comparsas também morreram. Nesse contexto de desolação e extrema miséria, o narrador também desconstrói e transcontextualiza a passagem bíblica da crucificação de Cristo, uma vez que é proposta pelo povo a crucificação de Sianga. Este é classificado pela gente de Mananga como um engodo, um anticristo e um anti-herói que nada salvou.

Depois do massacre comandando por Sianga na aldeia, o que restou para os sobreviventes de Mananga foi deslocar-se em busca da Aldeia do Monte: a possível terra prometida, porque somente restou na aldeia, depois do morticínio, um "rio de sangue", (CHIZIANE, 1999, p. 141). É essa necessidade de deslocamento dos sobreviventes de Mananga que evidencia no romance de Chiziane a temática do êxodo. Dentro da óptica dessa análise, o êxodo pode ser lido como o percurso entre a vida e a morte: a travessia, a mudança de perspectiva que une o princípio e o fim de tudo, o último reduto de esperança. E a guerra é motivadora desse êxodo 
no romance: a guerra pela sobrevivência, a guerra pela independência, a guerra civil pelo poder.

Dialogando com a morte, nessa primeira parte do livro encontra-se, no outro polo da presente análise, a temática da vida. Essa temática se personifica a partir da natureza que traz os seus cantos, propiciando a harmonia através da chuva, esperança que promete comida farta. O ritual tradicional da Mbelel é praticado em Mananga, e nele o feminino é fertilidade e revela-se, claramente, nesse chamado da mulher para garantir a fartura e a sobrevivência: "É o ventre que se rasga no princípio da vida”. (CHIZIANE, 1999, p. 88). Nesse ritual, o sacrifício de animais é oferecido à vida enquanto as mulheres dançam nuas, à musica de mulheres, porque, segundo o narrador, "a mulher é a mãe do universo". (CHIZIANE, 1999, p. 99). "Os ventres de todos estão dilatados, mas os das fêmeas, para além da fome, também incubam amor e vida, último suspiro de esperança". (CHIZIANE, 1999, p. 110).

É perceptível que a mulher, em muitas passagens do romance, é colocada como ícone da vida. A vida também é exaltada no romance através do amor entre o negro Dambuza e Wusheni, filha de Sianga e Minosse, sinalizando o renovar das gerações, uma vez que Wusheni fica grávida de Dambusa, e a vida é coroada pela gestação de um filho através da alegria do amor idealizado e do erotismo. A temática da vida é recorrente também na configuração da alegria das crianças de Mananga, pois elas eram vistas como "eternos foliões [...]" (CHIZIANE, 1999, p. 67). A música é outra categoria que, no romance, marca o compasso do ritmo da existência, pois ela é o que anima holisticamente a vida, como o próprio narrador afirma: "o universo é musicado". (CHIZIANE, 1999, p. 75). Nesse viés, os tambores, para a tradição do povo de Mananga, despertam a terra adormecida nos rituais de Mbelele. O narrador evidencia que o canto das gentes de Mananga é pela exaltação da existência, pois as mulheres que clamam pela água não temem a morte, mas amam a vida e não querem perdê-la. Em uma passagem do romance, isso é evidenciado através do registro de um poema que faz reverência afirmativa à vida, quebrando, inclusive, a linearidade da narrativa em prosa:

Vida,

Apesar das amarguras

Eu amo-te

Com as suas delícias e malícias

Adoro-te.

(CHIZIANE, 1999, p. 96). 
Chiziane, nesse trecho, pincela a narrativa de imagens poéticas, escritas com ritmo do canto africano que ela insere em sua estética em prosa. Nesse quesito, Ventos do Apocalipse, ao que tudo indica, se estrutura formalmente por interconexões da prosa e da poesia, do canto e do silêncio, da ação narrativa e da contemplação descritiva, e ainda por disseminações de apelos dramáticos de chamamentos ao interlocutor, evidenciados por verbos no imperativo. Percebe-se, portanto, que também há, no romance, a recriação estética de um ritmo fragmentado e sincopado de representações temáticas sobre a vida e a morte, sobre a violência e a guerra. Talvez esse seja o modo pelo qual Chiziane procure formalmente tecer, em seu registro ficcional, testemunhos de um país destroçado pela guerra civil, articulando e desarticulando culturas, línguas e tradições diferentes em uma só história e possibilitando ao leitor um estranhamento reflexivo-formal ligado aos temas tratados.

Nessa perspectiva estética, vale a pena lembrar Jaime Ginzburg quando afirma, a partir de fragmentos da teoria estética de Adorno, que "a forma conforma o conteúdo". (GINZBURG, 2012, p. 182). Baseando-se em Adorno, Ginzburg afirma que "as ideias estéticas são interpenetradas fortemente com concepções religiosas - imagens de divindade, elementos de diferentes tradições mitológicas, códigos cristãos". (GINZBURG, 2012, p. 182). Ainda segundo Ginzburg, para Adorno nem a arte nem a vida têm síntese positiva. Esses conceitos nos servem para perceber que a forma fragmentada da estética de Ventos do Apocalipse, com períodos simples e pouco subordinados, indica um texto em soluços, assim como a organização dos capítulos. Em um capítulo, o personagem tem vida, em outro ele não mais existe, como se a vida acendesse e a morte apagasse os rastros dos homens. Muitos personagens são deixados pelo caminho, esquecidos e silenciados ainda dentro da narrativa. A morte como perda, esquecimento é representada tanto na forma com no conteúdo do romance. Nesse viés é possível pensar que a vida, em Ventos do Apocalipse, é linguagem e discurso, enquanto que a morte é silêncio, lacuna e fragmentação de sentidos.

Nota-se também que Chiziane executa nessa obra um canto escritural que hibridiza a tradição mítica das narrativas circulares e previsíveis com a perspectiva moderna, caracterizada pela imprecisão e abertura de sentidos, que, na óptica de Adorno, não mais privilegia a totalidade na forma, mas institui um tipo de arbitrariedade na experimentação criativa. Nessa perspectiva, a ambiguidade é instituída na narrativa e podemos vê-la, por exemplo, na categoria do vento, que nessa primeira parte traz tanto a esperança de mudanças quanto a própria violência da morte. Sua função é ambígua, assim como a morte e a vida. Passagens como 
estas confirmam essa nossa assertiva: "Sopram ventos de novas mudanças e tudo voltará a ser como antes" (CHIZIANE, 1999, p. 49) ou "Do sul sopra um vento forte [...] as folhas caem com violência [...]”. (CHIZIANE, 1999, p. 114).

Há ainda em Ventos do Apocalipse um exercício escritural em que a narrativa escrita resgata a narrativa oral, e ambas costuram a arquitetura da obra. Walter Benjamin, ao analisar a categoria do narrador na obra de Nikolai Leskov, afirma que a arte de narrar está em vias de extinção, porque as pessoas parecem ter perdido a "faculdade de intercambiar experiências" (BENJAMIN, 1994, p. 1) e porque a "sabedoria - o lado épico da verdade - está em extinção". (BENJAMIN, 1994, p. 3). Benjamim elenca, nesse texto, dois motivos para a extinção da narrativa: o romance e a informação; o primeiro seria responsável por isolar o indivíduo e lhe impossibilitar falar de suas preocupações e dar e receber conselhos, e o segundo giraria em torno dos fatos explicados, que desvalorizariam o exercício narrativo da memória coletiva, não comprovável e atemporal.

Ao analisarmos a perspectiva narrativa de Ventos do Apocalipse, é possível dizer que o narrador contraria a visão pessimista benjaminiana sobre o narrador dos romances modernos. Ao que tudo indica, Chiziane tece uma história na qual o narrador, além de figurativizar e ficcionalizar, em muitas camadas, o tema factual da guerra civil moçambicana e da violência extrema gerada por essa guerra póscolonial, costura como um artífice, no texto, a ideia de eternidade da morte e da vida, por meio de provérbios, superstições e profecias da tradição do povo africano. A morte e a vida, no, romance deixam de ser apenas fatos de guerra historicizados para adquirem também um tom de autoridade e sabedoria milenar. E é nessa alternância entre referências factuais e imaginárias, modernidade e tradição que a escritora desenha uma escrita aparentemente em solavancos, comprometendo-se performaticamente com as imagens dos impactos da guerra e dos massacres violentos, mas também se aliando a um tempo mítico de verdades eternas e imutáveis. Como afirma Benjamin, "A morte é a sanção de tudo o que o narrador pode contar”. (BENJAMIN, 1994, p. 7). Portanto, há lacunas que são deixadas propositalmente na obra de Chiziane para a reflexão do leitor, sejam elas sobre a barbárie da guerra, sejam elas sobre a condição humana. O fato é que se percebe nesse romance a confirmação das afirmações teóricas de Adorno de que: "A forma é mediação enquanto relação das partes entre si e com o todo e enquanto plena elaboração dos pormenores." (ADORNO, 1988, p. 166). 


\section{Karingana wa Karingana, "era uma vez" a imprevisibilidade da morte e da vida}

Na segunda parte do livro, a circularidade da vida e da morte parece ser interrompida, pois as certezas do povo de Mananga se tornam incertezas. $\mathrm{O}$ canto da tradição que marcava o ritmo do tempo - "cada ano, cada ano tem a sua história. Cada dia, cada dia tem a sua história” (CHIZIANE, 1999, p. 145) - é substituído pelo canto do desespero, da dúvida, do medo: "E amanhã? Não sei o que irá acontecer." (CHIZIANE, 1999, p. 145). O fragmento da epígrafe da segunda parte dialoga com o provérbio da primeira parte do romance: "nasceste tarde, verás o que eu não vi.". (CHIZIANE, 1999, p. 146). Depois do massacre de Mananga, aqueles que restaram têm um caminho traçado pelo narrador: "resta apenas um caminho: assinar o divórcio com a vida e transformar-se em poeira que o vento fará levantar [...]" (CHIZIANE, 1999, p. 146). Na narrativa é perceptível que, para esses sobreviventes, não existirá mais nenhuma previsibilidade do destino, pois para eles os deuses da tradição estariam mortos. Essa ideia que aflora na narrativa abre possibilidade de pensar a violência pós-barbárie na perspectiva de Adorno, que a aponta como uma tensão "incontornável, incompatível com qualquer justificação”. (ADORNO apud GINZBURG, p. 193). Sem um destino previsível, a única esperança que motivava os dois grupos de cerca de sessenta refugiados que sobreviveram ao morticínio da aldeia de Mananga era a perspectiva de chegada à terra prometida, que eles denominaram de Aldeia do Monte.

O narrador, nesse momento da narrativa, institui a ironia para mediar o diálogo da morte e da vida no êxodo para a terra prometida: "os corpos vivos marcham como sepulcros, como duendes, como sombras mortas". (CHIZIANE, 1999, p. 148). A natureza é irônica e "ri dos insensatos". (CHIZIANE, 1999, p. 149).

A morte, nessa óptica, assume muitas representações. Na trajetória dos refugiados de Mananga até a terra prometida, a loucura e a jiboia ceifam o personagem Doane, que rejeita, pelo medo, o nascimento do seu próprio filho. O medo se traveste, ainda, de morte nessas passagens da história, e aviões de guerra entram no palco da narrativa: "agora voam por cima das suas cabeças mais ameaçadores que os abutres”. (CHIZIANE, 1999, p. 160). É um cenário de desolação e miséria total, em que a guerra faz a permuta entre as duas faces da vida e da morte quando o narrador afirma: "São duas vidas que se saúdam no cruzamento dos caminhos. Uma na partida e outra na chegada. Enquanto do lado de lá as vidas se esfumam, deste lado nascem e mantêm viva a semente da esperança”. (CHIZIANE, 1999, p. 162). Essa força negativa faz a morte se unir ao fogo e também ceifar vidas: "o fogo intensificava-se e o espetáculo foi terrível; 
os homens morriam, uns de pé, outros ajoelhados ou deitados, uns a rir, outros a sorrir, uns a gemer, outros a chorar". (CHIZIANE, 1999, p. 164).

Mas não é somente o fogo que se entrelaça com a morte; a chuva, que na primeira parte do livro era motivo de esperança e sinônimo de fartura, se transforma, na segunda parte do romance, em exterminadora. A chuva, nessa perspectiva, inunda terras e causa doenças fatais, como a diarreia, nos sobreviventes de Mananga e da Aldeia do Monte. A água, que antes poderia salvar pessoas, passa a matar e contaminar os refugiados de Mananga que chegaram à terra prometida da Aldeia do Monte. A natureza é mais uma vez personagem ambíguo: ora avisa a vida, ora anuncia a morte. Como a sábia Minosse em seu delírio define:

a terra é uma mãe estranha. Os mistérios dos homens acontecem nos olhos dela. Os caminhos dos homens traçam-se no dorso dela, mas esta mãe olha para tudo com uma indiferença absoluta, não protege e nem desprotege e deixa que os insensatos matem por ela e se proclamem heróis. (CHIZIANE, 1999, p. 256).

Ventos do Apocalipse parece constituir-se, para Chiziane, numa tentativa de narrar o inenarrável. As atrocidades da guerra civil moçambicana, de tão bárbaras, violentas e desumanas, adquirem no romance um caráter traumático e quase surreal de holocausto. Na segunda parte de Ventos do Apocalipse, o trauma intermedia também as duas categorias morte e vida. Os refugiados de Mananga são silenciados pelo horror do massacre humano de filhos, pais, mães, maridos: "o silêncio cresce". (CHIZIANE, 1999, p. 150). E mais uma vez o narrador configura a face da morte nesse trecho como uma personagem silenciosa e traiçoeira: "[a] morte nunca se projeta pomposa como as fanfarras de um cavaleiro real. É traiçoeira, é invisível, morde as costas, a cobarde." (CHIZIANE, 1999, p. 152). Em outra passagem é dito: "o silêncio é maldito, tenebroso, paira o feitiço no ar, minha gente! [...] O silêncio só reina quando a morte passa". (CHIZIANE, 1999, p. 166).

No romance, a personagem Minosse assume a silenciosa figura do trauma, já que "os desgostos fizeram dela uma pessoa morta. Ela é um fantasma." (CHIZIANE, 1999, p. 155). "As imagens do horror testemunhadas por aquele povo naquela tarde reduziram ainda mais o moral dos viajantes. Ninguém as comenta porque o comentar é um reviver. O sofrimento é fermento da alma, dizem [...] para manter a alma sempre desperta". (CHIZIANE, 1999, p. 171).

Márcio Seligmann-Silva, citando o pensamento de Dori Laub e de Primo 
Levi, afirma que há eventos como o holocausto que são sem testemunhas ou com testemunhos parciais, uma vez que o grau de violência deles é tão extenso que as testemunhas não poderiam se afastar do evento para "poder gerar um testemunho lúcido e íntegro”. (SELIGMANN-SILVA, 2008 p. 67). Seligmann-Silva diz também, a partir do pensamento de Primo Levi, que o "trauma é caracterizado por um passado que não passa”. (SELIGMANN-SILVA, 2008 p. 69). Já tomando a óptica de Helene Piralian, o crítico defende que "para o sobrevivente sempre restará esse estranhamento do mundo advindo do fato de ele ter morado como que 'do outro lado' do campo simbólico". (SELIGMANN-SILVA, 2008, p. 69). E para tentar amenizar a lacuna silenciosa entre a experiência e a narração de eventos traumáticos, Seligman-Silva, citando consideração de Robert Antelme, afirma que a imaginação apresenta-se como meio para enfrentar a crise do testemunho: “A imaginação é chamada como arma que serve-se ao simbólico para enfrentar o buraco negro do real do trauma [...]. A literatura é chamada diante do trauma para prestar-lhe serviço". (ANTELME apud SELIGMAN-SILVA, 2008, p. 70). E o único modo que esse estudioso percebe como saída para os sobreviventes de traumas é o que condiz com o pensamento de George Perec: "narrar o trauma, portanto, tem em primeiro lugar este sentido primário de desejo de renascer". (PEREC apud SELIGMAN-SILVA, 2008, p. 66).

Nesse romance de Chiziane, o exercício da narrativa do trauma como ato terapêutico é percebido a partir dos três órfãos adotados por Minosse. Todos eles renascem para a vida quando confiam na mulher que os acolhe. Sara, um dos órfãos, parece renascer ao narrar a sua história macabra do enterro dos pais vivos, e até a própria Minosse se renova quando exercita a memória e faz um balanço, no final do romance, do caminho trilhado por ela na vida ao perceber o chamado de sua morte.

Outros personagens de Chiziane, como a viúva Minosse, no final da vida, percebem a realidade além dos eventos bárbaros que experimentaram e que geraram neles o silêncio traumático - no caso de Minosse, esses eventos incluem a perda do marido e a morte de seus dois filhos. Ela olha para o passado e vê a barbárie que a história construiu, assim como a alegoria do anjo de Klee citado por Walter Benjamin ${ }^{3}$. Minosse também percebe que o vento do Apocalipse da guerra

3 No texto "Sobre o conceito de História", Walter Benjamin, ao falar da história, refere-se a um quadro de Klee que se chama Angelus Novus. Segundo Benjamin, ele "representa um anjo que parece querer afastar-se de algo que ele encara fixamente. Seus olhos estão escancarados, sua boca dilatada, suas asas abertas. $\mathrm{O}$ anjo da história deve ter esse aspecto. Seu rosto está dirigido para o passado. Onde nós vemos uma cadeia de acontecimentos, ele vê uma catástrofe única, que acumula incansavelmente ruína sobre ruína e as dispersa a nossos pés. Ele gostaria de deter-se para acordar os mortos e juntar os fragmentos. Mas uma tempestade sopra do paraíso e prende-se em suas asas com tanta força que 
civil moçambicana a impele para o futuro, que é o chamado de sua própria morte, que não poupa ninguém. O princípio e o fim se encontram na memória de Minosse, e ela sabe que o novo e o velho se perpassam. A história será recontada pelos seus filhos órfãos que também caminham, pois para Minosse a vida é um caminho, e a guerra e o trauma serão recorrentes nela, seja por meio de narrativas ficcionais ou não. Já Chiziane, ao construir personagens que, a partir de seus traumas passados, percebem o futuro, sinaliza para o leitor o seu comprometimento ético com a morte e a vida do outro: o povo moçambicano.

Nessa segunda parte de Ventos do Apocalipse, Chiziane também cria personagens que evidenciam o compromisso com a vida. Sobre o pano de fundo da violência, guerra e morte, ela sobrepõe quadros que evidenciam a categoria da vida, de valores como união, persistência, esperança, fraternidade e heroísmo. Sixpence, por exemplo, é o personagem eleito, assim como o Moisés bíblico, para conduzir os refugiados de Mananga pelas savanas até a Aldeia do Monte. Ele é piedoso, justo e acolhedor da vida. Sixpence acolhe órfãos e não abandona os doentes. Percebem-se nele traços de um herói épico, que corajosamente representa, por ações individuais, a face da tradição de um povo, como afirma o próprio narrador: "Sixpence é um herói e um campeão, ensina a lição da humanidade sem uma única palavra [...] o povo inteiro vê nele o salvador e precisa dele para alcançar terra firme". (CHIZIANE, 1999, p. 170-171). Todavia, esse traço positivo do caráter de Sixpence se perde na narrativa, pois o destino dele, assim como do povo de Mananga na Aldeia do Monte, é trágico, pois ele é batizado pelo fogo e pela morte.

A perspectiva da vida também chega à Aldeia do smOntes com o cartão de visita da filantropia. Grupos de enfermeiros prestam ajuda àquele povo e, com o auxílio beneficente do estrangeiro, a fome é minimizada e um cenário de festa passa a aflorar e reinar na aldeia por algum tempo. Mas não por muito tempo, pois o local também sofre a imprevisibilidade da vida e da morte. Esta logo retorna à Aldeia do Monte e, no final do romance, ela, ciclicamente, assume a lenda da história da moça Massupai contada no prólogo da narrativa.

Nesse momento, Massupai é protagonizada por Ermelinda, que é a própria face da loucura, do mistério e da traição de seu povo. O narrador, inclusive, deixa isso insinuado: "Enquanto nós dormimos, ela desperta, vagueia pela rua todas as noites [...] até parece que está a informar os passos da nossa vida a qualquer outra pessoa [...]." (CHIZIANE, 1999, p. 271). Ermelinda, no alto do Monte, sorri ironicamente 
diante do massacre apocalíptico que presencia de todo o povo da aldeia em que vivia. Mascarada pela loucura de Ermelinda, a morte ceifa novamente as vidas na terra prometida, onde, por um tempo, reinou a paz e a festa. Nessa cena de morticínio, Ermelinda, a Massupai de Chiziane, urina e ri até perder o fôlego, e percebe-se que a lenda africana se repete novamente, em novo contexto e com novas nuances. Ermelinda também é morta no massacre junto com seu filho. A morte, nesse cenário trágico da Aldeia do Monte, tem, mais uma vez, face irônica, pois Emerlinda, que parecia ter renascido para a vida quando quebrou o mutismo, contando a sua história para a enfermeira, de maneira imprevisível faz opção pela morte. Ermelinda morre como traidora pelo tiro da guerra que lhe atravessa, juntamente como o filho, o peito. A morte apaga vidas com o batismo do fogo na Aldeia do Monte: morte e vida, ambas imprevisíveis.

\section{Conclusão}

Ao que tudo indica, Paulina Chiziane escreve um romance que, de um modo ficcional, procura testemunhar o trauma da guerra civil vivida pelo povo de Mananga, que migra para a Aldeia do Monte. É possível considerar, a partir das reflexões realizadas, que em Ventos do Apocalipse Chiziane usa o imaginário para tocar o real e romper o silêncio da história oficial sobre os genocídios da guerra civil moçambicana. Como diz Tânia Pellegrini (2007), o pacto realista continua nos romances contemporâneos. E Chiziane, em Ventos do Apocalipse, parece exercitar a ideia de refração pregada por Pellegrini, em que se possibilita uma visão do todo e da parte numa perspectiva de prisma que, além de questões estéticas, emoldura também temas extraliterários como ética e política. De modo fragmentado, Ventos do Apocalipse deixa de ficcionalizar apenas um acidente na história do país para se tornar meio de reflexão e discussão de pontos muito mais abrangentes que possivelmente Moçambique ainda vivencia. Nesse viés, percebe-se que há, por parte de Paulina Chiziane, ao escrever o romance, um comprometimento ético com o futuro do povo de seu país. E isso é notório na narrativa, principalmente a partir do personagem do velho e sábio Mugoni, que explica aos mais jovens da Aldeia do Monte a causa da guerra e da morte como sendo decorrente do confronto do "velho" e do "novo". Esse personagem fornece, didaticamente, para o leitor, as pistas da hecatombe que assolou Moçambique nos tempos de guerra civil e adverte que se deve evitar os confrontos entre o tradicional e a modernidade estrangeira, no que se refere à identidade cultural e 
religiosa do povo africano. Há passagens no romance que dizem que a tradição deve ser respeitada, e a ética, vivenciada: "a crise existe porque o povo perdeu a sua ligação com a sua história. [...] qualquer desenvolvimento só é perfeito quando tem uma raiz que o sustenta" (CHIZIANE, 1999, p. 266-267). Nesse sentido, Chiziane aponta para aquilo que não é explícito em sua ficção, o melhor caminho que poderia unir futuramente os eixos da vida e da morte em Moçambique. Enquanto esse ideal não é configurado, ela deixa para nós, leitores, o registro ficcionalizado da trágica e abrupta narrativa de violência e guerra de uma geração africana que, inadvertidamente, experimentou o Apocalipse: o deslizamento da vida no nascedouro da morte, sem nenhum caminho possível de libertação.

\begin{abstract}
The aim of this paper is to promote discussions and reflections about novel Ventos do Apocalipse, by Paulina Chiziane, uses the imaginary to witness traumas of the Mozambican civil war, articulating the life and death categories from images of violence and war. To do so, we will use discussions about the legitimacy of violence in literature, trauma, testimony, story, narrator and realism according to Jaime Ginzburg - who analyzes the thought of Hegel and Adorno -, Márcio Seligmann-Silva, Cathy Caruth, Walter Benjamin and Tânia Pellegrini. The methodology will be qualitative-interpretative, based on descriptive and comparative analyzes of literary and theoretical texts. Our hypothesis is that Ventos do Apocalipse is structured in a dialogical, sliding axis of two categories: life and death, around which are intertwined images of violence and war as actions that build the diegesis of the novel and simultaneously reinforce an ethical compromise of the writer Chiziane with the testimony of the trauma of the civil war experienced by the Mozambican people.
\end{abstract}

Keywords: African literature. War. Violence. Trauma. Testimony. Life. Death.

Referências

BARBEITOS, Arlindo. Oliveira Martins, Eça de Queiroz, a raça e o homem negro. In: Actas da III Reunião Internacional de História de África: a África e a Instalação do Sistema Colonial (c.1885-c. 1930). Centro de Estudos de História e Cartografia Antiga do Instituto de Investigação Científica Tropical. Lisboa, 2000. 
BENJAMIN, Walter. Magia e técnica, arte e política: ensaios sobre literatura e história da cultura. Tradução de Sérgio Paulo Rouanet. São Paulo: brasiliense, 1994, p. 197-221.

CARUTH, Cathy. Modalidades do despertar traumático (Freud, Lacan e a ética da memória). In: NETROSVISKI. A; SELIGMANN-SILVA. M. (Org.). Catástrofe e representação: ensaios. São Paulo: Escuta, 2000.

CHIZIANE, Paulina. Ventos do Apocalipse. Lisboa: Caminho, 1999.

FONSECA, Maria Nazareth Soares; MOREIRA, Terezinha Taborda. Panorama das Literaturas Africanas de Língua Portuguesa. In: FONSECA, Maria Nazareth Soares; MOREIRA, Terezinha Taborda (Org.). Cadernos CESPUC de Pesquisa. n. 16. Belo Horizonte: Editora PUCMinas, 2007.

GINZBURG, Jaime. Violência e Forma em Hegel e Adorno. In: SELIGMANN-SILVA, M. GINZBURG; J. Hardman, F. F. (Org.). Escritas da violência: representações da violência na história e na cultura contemporâneas da América Latina. Rio de Janeiro: 7 Letras, 2012.

LEITE, Ana Mafalda. Tópicos para uma história literária moçambicana. In: MENESES, Maria Paula; RIBEIRO, Maria Calafate. (Org.) Moçambique: das palavras escritas. Porto: Editora Anfrontamento, 2008.

PELLEGRINI, Tânia. Realismo: postura e método. In: Letras de Hoje. Porto Alegre. v. 42, n. 4, p. 137-155, dezembro 2007.

SELIGMANN-SILVA, Márcio. Narrar o trauma. A questão dos testemunhos de catástrofes históricas. Psicologia Clínica. Rio de Janeiro, vol. 20, n.1, p. 67-68, 2008 .

THEODOR, Adorno. Prismas: crítica cultural e sociedade. Tradução de Augustin Wernet e Jorge de Almeida. São Paulo: Ática, 1998. 